\title{
Epithelioid Cell Uveal Melanoma
}

National Cancer Institute

\section{Source}

National Cancer Institute. Epithelioid Cell Uveal Melanoma. NCI Thesaurus. Code C35780.

A uveal melanoma characterized by the presence of malignant large epithelioid melanocytes. 